\title{
Clinical utility of cardiac magnetic resonance T2 mapping for acute myocardial edema
}

\author{
Asad A Usman*, Marie Wasielewski, Jeremy D Collins, Mauricio S Galizia, Andrada R Popescu, James C Carr \\ From 2011 SCMR/Euro CMR Joint Scientific Sessions \\ Nice, France. 3-6 February 2011
}

\section{Objective}

To evaluate the potential clinical utility of T2 quantitative mapping for myocardial edema in acute disease pathology - myocarditis, myocardial infarction, TakoTsubo cardiomyopathy, and transplant rejection.

\section{Background}

Edema is a generic tissue response to acute myocardial injury and, therefore; a potential marker of impending tissue damage. Currently in clinical use, T2 weighted imaging provides a qualitative technique in assessing myocardial edema. We hypothesize that quantitative T2 mapping in patients with suspected cases of myocarditis, myocardial infarction (AMI), and cardiac transplant rejection will provide a more sensitive and specific diagnostic prediction than with $\mathrm{T} 2 \mathrm{~W}$ imaging, and add to other imaging techniques.

\section{Method}

We used a non-contrast multiplanar single-shot and cine TrueFISP and steady state free precession (SSFP) sequence developed by Siemens Healthcare which consists of T2-prepared, linear flip angle series of 20, 60, and 90 degrees, and SSFP readout. ECG triggered breathold T2 mapping was done on the three short axis and 4 chamber images on a $1.5 \mathrm{~T}$ scanner (MAGNETOM Avanto, Siemens Erlangen, Germany). Regions of interest (ROI) based on the 17 segment myocardial model were drawn by two blinded reviewers (AU and MW) for inter-rater and intra-rater reliability.

\section{Results}

Complete results are presented in table 1. T2 mapping was done on 6 suspected acute myocarditis, 13 AMI, 1 Tako-Tsubo cardiomyopathy, and 25 transplant patients.

Table 1 Demographics

\begin{tabular}{|c|c|c|c|c|c|}
\hline Total cases & 65 & & & & \\
\hline Group & Controls & Transplant & AMI & Myocarditis & Cardiomyopathy \\
\hline Average age & $32.7 \pm 7.3$ & $55.8 \pm 13.8$ & $55.5 \pm 10.3$ & $49.2 \pm 13.2$ & 60 \\
\hline Percent female & $50 \%$ & $44 \%$ & $33 \%$ & $33 \%$ & $100 \%$ \\
\hline Normal** & 20 & 22 & 4 & 3 & 0 \\
\hline Disease & NA & 3 & 8 & 3 & 1 \\
\hline Total & 20 & 25 & 12 & 6 & 1 \\
\hline \multicolumn{6}{|l|}{ Outcomes } \\
\hline Average T2 Normal ROI (ms) & $51.2 \pm 2.7$ & $52.1 \pm 2.4$ & $54.1 \pm 3.1$ & $54.0 \pm 3.7$ & $52.3 \pm 3.1$ \\
\hline Average T2 Disease ROI (ms) & NA & $61.6 \pm 3.1$ & $65.0 \pm 4.4$ & $67.1 \pm 7.5$ & $68.0 \pm 4.2$ \\
\hline Significance & NA & $<0.05$ & $<0.05$ & $<0.05$ & $<0.05^{*}$ \\
\hline Ejection fraction & $62 \%$ & $58.7 \%$ & $39 . \$ \%$ & $41 / 1 \%$ & $32.2 \%$ \\
\hline
\end{tabular}

*p-value compared internally from basal segment to mid and apical segment.

** Normal represents cases that were suspected to have outcome, i.e. AMI, myocarditis, etc, but were by clinical assessment MRI, and cellular pathology determined not to have any disease. These cases T2 Mapping were compared to cases with in-group pathology. 


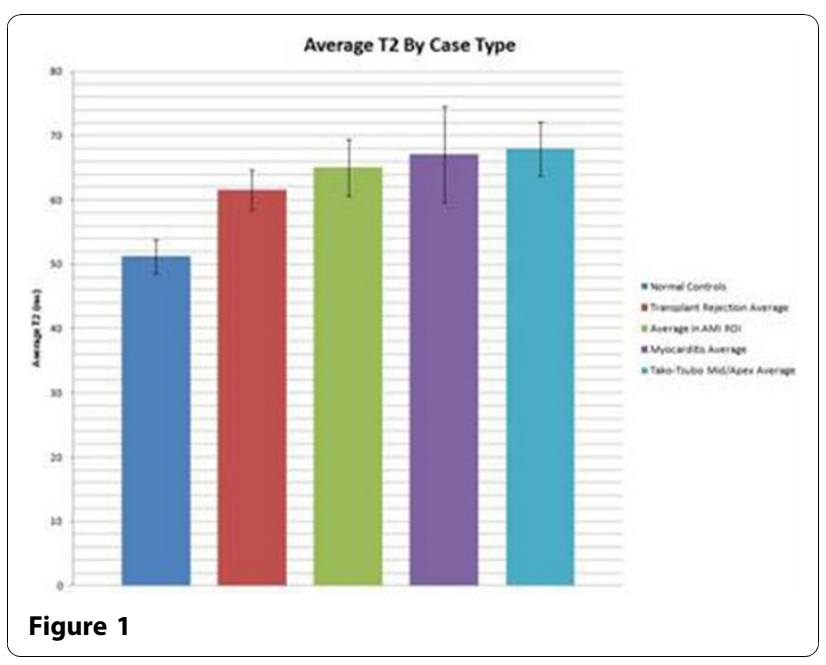

The average age of all patients was $50.9 \pm 7.8$ years old, $62 \%$ male, and average scan time was 45 minutes. Control studies on normal patients demonstrated a global T2 mapping average of $51.2 \pm 2.7 \mathrm{~ms}$. Of the 6 patients with suspected myocarditis 3 were found to have no myocarditis based on MR criteria and clinical follow-up (100\% concordance with T2 mapping). The 3 patients with myocarditis had cardiac sarcoidosis, viral, and giant cell myocarditis with average $\mathrm{T} 2$ of $70.6 \pm 6.7 \mathrm{~ms}$ $(\mathrm{p}<0.05) .10 / 12$ suspected AMI patients had segmentally concordant $\mathrm{T} 2$ values in relation to delayed enhancement outcomes. The average infract segment $\mathrm{T} 2$ value was $66.4 \pm 3.2 \mathrm{~ms}(\mathrm{p}<0.05)$. The basal $\mathrm{T} 2$ value in the Tako-Tsubo case was $52.3 \pm 3.2 \mathrm{~ms}$, while the mid and apical average were $68.0 \pm 4.2 \mathrm{~ms}(\mathrm{p}<0.05)$. Figure 1

\section{Conclusions}

T2 quantification provides a useful clinical tool in evaluating cardiac pathology with acute cellular responses and edema. We hope with advances in spatial and temporal resolution T2 mapping can be used to determine myocardial viability in cases of AMI, predict transplant rejection, or help rule-out myocarditis.
doi:10.1186/1532-429X-13-S1-0101

Cite this article as: Usman et al: Clinical utility of cardiac magnetic resonance T2 mapping for acute myocardial edema. Journal of Cardiovascular Magnetic Resonance 2011 13(Suppl 1):0101.
Submit your next manuscript to BioMed Central and take full advantage of:

- Convenient online submission

- Thorough peer review

- No space constraints or color figure charges

- Immediate publication on acceptance

- Inclusion in PubMed, CAS, Scopus and Google Scholar

- Research which is freely available for redistribution

Submit your manuscript at www.biomedcentral.com/submit
C Biomed Central 